The University of San Francisco

USF Scholarship: a digital repository @ Gleeson Library | Geschke Center

Finance

School of Management

2011

\title{
The Economic Value of a Sustainable Supply Chain
}

Robert Mefford

University of San Francisco, mefford@usfca.edu

Follow this and additional works at: http://repository.usfca.edu/fe

Part of the Finance Commons, and the Marketing Commons

\section{Recommended Citation}

Robert N. Mefford. The Economic Value of a Sustainable Supply Chain. Business and Society Review. Volume 116, Issue 1, pages 109-143, Spring 2011. http://dx.doi.org/10.1111/j.1467-8594.2011.00379.x

This Article is brought to you for free and open access by the School of Management at USF Scholarship: a digital repository @ Gleeson Library | Geschke Center. It has been accepted for inclusion in Finance by an authorized administrator of USF Scholarship: a digital repository @ Gleeson

Library | Geschke Center. For more information, please contact repository@usfca.edu. 


\title{
The Economic Value of a Sustainable Supply Chain
}

\begin{abstract}
The economic rationale to operate a global supply chain in a sustainable manner is developed. Arguments are made based on marketing, finance, and production theories that by engaging in socially responsible behavior the firm will increase sales, decrease costs, reduce financial risk, and increase profits which ultimately will increase returns to the firm's shareholders. A model is developed of the mechanism by which modern production methods such as lean production and quality management result in sustainable corporate behavior which, in the long run, translates into higher stock valuations. The production effects cause marketing and financial risk effects that are complementary, and all three channels of influence synergistically result in higher stock values in the model. These effects also provide important benefits to other stakeholders of the firms including employees, customers, the environment, and the community. An important ethical issue in global supply chains is working conditions in foreign plants often leading to allegations of sweatshop labor conditions. This issue is used to illustrate how lean production practices can affect consumers, employees, and financial risk. Conclusions from the sweatshop labor issue are shown to apply to other sustainability issues as well.
\end{abstract}

Keywords: supply chain, lean production, sustainability, corporate social responsibility, sweatshop labor

\section{Introduction}

With the ongoing corporate scandals, many argue the case for corporate ethics. Governments have responded with greater oversight of corporate activities. More attention is being paid to corporate accounting and auditing practices. Business schools have added courses on ethics and sustainability. Many companies have developed statements of their corporate ethics, and some have incorporated these into Codes of Conduct. However, many of these efforts at Corporate Social Responsibility (CSR) appear to be driven more by public pressure rather than true ethical beliefs (Keller, 2003; van Tulder and Kolk, 2001). These efforts generally focus on the moral rationale for appropriate corporate behavior, but an economic argument can also be made for sustainable corporate actions. Many of course would argue that the only social responsibility a firm has is to its shareholders. Milton Friedman makes this argument in his article "The Social Responsibility of Business is to Increase Its Profits" (Friedman, 1970). But what if socially responsible corporate behavior actually increases returns to shareholders? There is some emerging empirical evidence for this (to be cited later), and this paper develops a model of how this can result. Put simply, it may well pay off in terms of greater profitability and higher stock valuations for a company to pursue sustainable business practices. Sustainable business practices are defined as corporate policies and actions that attempt to satisfy the various stakeholder groups of the firm in order to insure long term competitiveness. This definition of sustainability expands the UN (1987) definition ("sustainable practices ensure that present needs are met without compromising the ability of future generations to meet their needs") to include other stakeholder groups in addition to the environment. In this paper sustainability and corporate social responsibility are seen as identical.

The economic justification for sustainable corporate behavior is multi-faceted. It includes the most obvious element of higher sales as consumers respond favorably to firms that they perceive to be ethical. However, there may be important productivity and cost benefits of engaging in sustainable business practices, which modern production theory suggests. There may also be important influences on employee behavior which in turn affect corporate profitability. In addition, there may be a significant reduction in financial risk by pursuing sustainable supply chain practices. There are also some synergies among these factors which overall can result in sustainable firms having higher revenues, lower costs, and reduced financial risk. The equity markets should reward such firms with higher stock valuations.

Many of the ethical dilemmas that firms encounter arise in their supply chains, particularly their global supply chains. This paper will focus on these and especially on an issue that receives much attention in global supply chains as well as negative publicity for many firms in the low technology apparel, shoe, and toy industries---sweatshop labor. The economic arguments made in this paper transcend this particular ethical issue to include environmental impact, bribery, anti-competitive practices, and others in global supply chains, but the sweatshop labor issue illustrates the economic arguments that also may apply for 
some of these other ethical issues.

The organization of this paper is as follows. Following the introductory section, the second section will develop the marketing arguments for sustainable supply chain practices. Section 3 presents the production arguments, drawing heavily on modern production theory, especially the concepts of lean production and quality management programs such as Six Sigma and Total Quality Management(TQM). Section 4 outlines the productivity and quality benefits of employing lean production methods in global supply chains. In Section 5 the effects on employee skills and morale of lean production practices will be discussed. Section 6 examines the potential reduction in financial cost and risk resulting from sustainable supply chain behavior. The benefits to shareholders of the firm of sustainable practices are considered in Section 7. In Section 8 the model of the linkages between sustainable supply chain practices and marketing, production, and financial effects which ultimately influence stock valuation is presented. Section 9 considers the benefits of sustainable supply chain practices to other stakeholder groups of the firm. Section 10 discusses the issues raised in the paper and draws some managerial implications. The last section of the paper summarizes the major points.

\section{Revenue effects of sustainable corporate behavior}

The behavior of many companies indicates that they believe that consumers do not really care about how they deal with their suppliers and employees, only being concerned with price. These firms argue that they must find the lowest cost supplier and relentlessly cut labor costs to remain competitive with cheap foreign competition. But not all firms accept this rationale believing that it matters what consumers think about a firm's sustainability practices (McWilliams and Siegel, 2000). Many managers, of course, pursue ethical corporate behavior just because they think it is the right thing to do. But some of these managers also think that it benefits their firms in terms of revenue effects. These involve higher sales and strong customer loyalty for firms perceived to be sustainable in their business practices, and the avoidance of buying from those firms they see as not. There are a few studies which support this contention. A survey of 25,000 consumers in 26 different countries by the consulting firm Pricewaterhouse Coopers in 1999 found that more consumers based their impression of a company on its CSR practices than on brand reputation or financial factors (PWC, 1999). This study indicates that the major CSR issues important to consumers are labor practices, business ethics, environmental practices, and demonstrated responsibility to society at large. In another study Auger, et al (2003) find that consumers prefer to buy products from companies they see as ethical.

The Service Profit Chain is proposed by Heskett, et al. (1994) to link customer satisfaction and loyalty in services to market performance. They define market performance to mean higher revenues and market share as well as profitability. Customer loyalty enhances market performance in their model by increased revenues, lower costs to acquire and service customers, and lower customer price-sensitivity. Several studies have lent empirical support to this model (Anderson, Fornell, and Rust, 1997; Rust, Zahorik, and Keiningham, 1995).

Brand equity has become an important marketing concept implying firms with strong brand equity develop a loyal and profitable customer base. McDonald Corporation's brand equity is estimated by PricewaterhouseCoopers at $\$ 26.4$ billion while Nike’s is $\$ 7.7$ billion (Keeler, 2003). Loyal customers will buy more, pay higher prices, and consolidate their business with a few preferred firms reducing the need to do extensive promotion and advertising by these firms. Brand equity, once degraded, is very difficult to regain, and even one instance of unethical practice may result in a permanent loss of customers. Research indicates loyal, repeat customers are much more profitable to a firm than new customers because of increased revenues and reduced costs to acquire and service customers as well as lower customer pricesensitivity (Reichheld and Sasser, 1990).

Strong brand equity not only makes for loyal customers who purchase more but also allows higher prices to be charged with less discounting required to match competitors' prices. Reinhardt (1999) discusses how differentiation of the product allows firms to charge a price premium. Thus brand equity has dual benefits, higher sales and higher prices, which lead to higher revenue for the firm. This can be a very important economic benefit for a company that is perceived as being socially responsible, and this factor appears to be increasing in importance in consumer purchase decisions in the industrialized countries as improvements in communication technologies such as the Internet and cell phones allow consumers to be more knowledgeable about a firm’s sustainability practices (Davis, et al, 2006). 
A study by Fornell and his colleagues at the University of Michigan supports the marketing channel effect on shareholder value (Hart, 2007). They found that companies highly rated on the American Customer Satisfaction Index (ACSI) of the University of Michigan outperformed the S\&P 500. Hart views the customer satisfaction influence on firm value as a long-term effect while managers often focus too much on short-term cost cutting and profit maximization.

The effect on customers of sustainable supply chain practices and the resultant pricing, sales, and revenue effects are shown in Figure 1. These "marketing channel" effects may, in turn, lead to higher share prices. The mechanisms shown in the diagram start with the supply chain behavior of the firm. If these practices are sustainable they can lead to consumer preferences for the firm's products and services and higher brand equity. This can increase sales and may make the firm's demand curve less price-elastic allowing it to raise prices (or at the least do less discounting). The higher revenues that result from greater sales and higher prices increase the firm's profits leading to a higher stock market valuation.

\section{Figure 1}

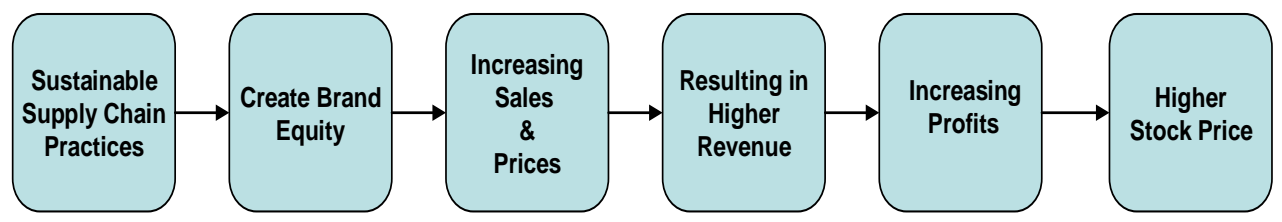

\section{Sustainable Supply Chain Linkages: The Marketing Channel}

The firm with a global supply chain must weigh the cost savings from lower labor costs that may arise with sweatshop conditions (and other unsustainable practices such as environmental pollution) against the possible negative publicity and harm to the firm's reputation from such practices. The effect on revenues of negative publicity and consumer boycotts is difficult to anticipate and quantify, but could ultimately lead to lower profitability of the firm as its brand equity is lessened. This is likely to be a long term result; however, encouraging firms to take advantage of immediate cost savings by sourcing from foreign plants with substandard working conditions (Hart, 2007). 
As the next section will discuss, sustainable business practices in the production area may significantly boost quality and productivity which in turn may lead to greater brand equity, higher sales and prices, and greater revenue complementing the marketing effects of sustainability. According to Womack and Jones (1996a) the ultimate goal of a lean production system is to provide value to the customer. This cross linkages between channels of influence will be discussed in the section of the paper presenting the complete model.

\section{Lean production and sustainable corporate behavior}

Contrary to the argument often used by firms as they seek the lowest cost source of supply, it may actually result in lower long-term production costs to pursue sustainable supply chain practices. The rationale for this argument lies in the concepts of lean production and quality management theories. In firms practicing lean production (often called Just-in-Time (JIT) production or the Toyota Production System) the emphasis is on elimination of waste (muda in Japanese) and improvement of quality through continuous process improvement. Concepts of jidoka (quality-at-the source) and kaizen (continuous improvement) are employed to accomplish these goals. These are not short-term goals, however, requiring years of dedicated process improvement efforts that involve training and empowering employees at all levels. Modern quality management programs such as Total Quality Management and Six Sigma are also process-oriented and share many of the same philosophical underpinnings and use some of the same methods as lean production. In fact, they often merge into programs such as Lean Six Sigma which firms such as Solectron and Lockheed-Martin are using. In this paper the emphasis will be on the lean production techniques, but a quality management focus would accomplish many of the same ends. Changing the philosophy and organization culture to implement lean production or quality management is essential, and this is usually the major reason firms fail at the attempt according to James Womack (Shah, 2006). Increasingly lean concepts are employed in service activities in the firm, the lean enterprise (Womack and Jones, 1996 b) and throughout the supply chain, the lean supply chain (Liker and Choi, 2004). Much of the material on lean production in this and the following two sections draws upon Ohno (1988), Shingo (1988), Spear and Bowen (1999), and Womack and Jones (1996 a \& b).

As firms attempt to spread the lean concepts of jidoka and kaizen to their supply chains they usually find it is a slow and expensive process to work with their suppliers and customers to get them onboard and adopt the same philosophy and practices. Firms that are successful at it such as General Electric and Toyota Motor Company spend years and millions of dollars (or yen) training their suppliers and customers and helping them introduce the lean concepts in their operations. The difficulty is compounded many fold when dealing with suppliers and customers in other countries with language, culture, and business environment differences. This has not prevented a few companies such as Honda and Toyota from doing so in their overseas operations (Liker and Choi, 2004). However, for those firms with a commitment to the lean philosophy and a long-term view, the potential benefits of spreading lean practices to their foreign suppliers may make it worthwhile.

The normal practice in global supply chains in the apparel and footwear industries is to use contract manufacturers in other countries that offer the lowest price while meeting minimal quality and delivery standards. Frequent switching of suppliers to take advantage of lower cost opportunities and favorable exchange rate changes is common. In this approach no loyalty is felt to the supplier, or by the supplier to the customer. For simple manufactures such as clothing, shoes, toys, and small appliances this supply chain strategy is preferred by most Multinational Enterprises (MNE) who believe it maximizes their competitiveness by being able to tap the lowest cost source of supply. Often the suppliers, who are typically subcontractors, have sweatshop conditions in their factories including the use of child labor, long hours without overtime pay, unhealthy and unsafe working conditions, and low wages, but the multinational firms using these suppliers absolve themselves of responsibility for such conditions saying that they do not own these facilities and cannot control their suppliers. A few, bowing to negative publicity, have established corporate Codes of Conduct, and some participate in audit programs of their foreign plants. The evidence so far is that most of the Codes of Conduct and audit programs have limited effectiveness as they are enforced with varying intensity and audits are usually sporadic and only involve a small number of plants (Locke, et al, 2007: Roberts and Engardio, 2006). The few audit results that have been released publicly confirm many of the abuses alleged by critics (Bernstein, 2003).

The lean production philosophy says that MNE's have an incentive other than avoiding negative 
publicity for insisting that their global suppliers follow their Codes of Conduct. It may actually lead to some important manufacturing benefits to have these suppliers treat their workers in more humane ways. In some cases, it might even suggest that the MNE's will have an incentive to operate their own foreign plants, rather than depend on subcontractors in order to have sufficient control to implement the change to a lean system and to have continuity in their global supply relations. What then are these benefits of a lean supply chain? The next section will discuss the potential production benefits of a lean and sustainable supply chain.

\section{$4 \quad$ Quality and productivity benefits of a lean supply chain}

Lean production facilities are characterized by high quality and efficiency (Womack and Jones, 1996b). They also tend to be more flexible to changes in product and volume and have shorter lead times than traditional manufacturing facilities (Zara's supply chain is a good example; see Ferdows, et al, 2004). These benefits are so important to competitiveness that the firms that have mastered lean production tend to dominate their industries. They achieve these benefits not only in their own plants but also in the facilities of suppliers by working closely with them to improve. In a few cases these close partnership relationships have been implemented internationally.

As these lean practitioners have discovered, it pays off in the long run to choose a higher cost capable supplier rather than simply selecting the lowest price bidder. They spend time visiting manufacturing facilities, examining financial statements, and talking to management at all levels of potential suppliers to gauge whether they are capable. What they define as a capable supplier is one who has implemented, or is able to implement, the lean philosophy and practices. They know that such a supplier will be practicing jidoka and kaizen and will continuously be improving quality and productivity. These suppliers will also be more flexible in responding to changes in products and volume and can deliver with shorter lead times. Some customers will willingly pay higher prices initially to achieve these benefits and expect to recoup them in the future with lower production costs and higher quality as the suppliers improve their efficiency and quality (Liker and Choi, 2004).

The organizational culture and management-labor relations necessary to implement a lean production system are incompatible with sweatshop labor conditions. Jidoka and kaizen require a welltrained, motivated, and empowered work force to assure that work is done correctly without supervision, and that workers are constantly looking for ways to improve processes. Sweatshop practices of minimal training and responsibility, strict supervision and rigid work rules, unpleasant and unsafe working conditions, low pay and high turnover make it impossible to develop the type of workforce required in lean production systems. In the short-run production costs may be low, but they will not decrease over time as productivity will be low and remain low, and quality will have to be inspected in and will not improve either.

Several recent studies provide evidence. Frenkel and Scott (2002) report on a comparison of two Adidas shoe manufacturing plants in China. Both are subcontract facilities owned by different Taiwanese firms. One has implemented lean practices involving worker responsibility for quality and teamwork while the other follows traditional manufacturing practices. The lean plant has fewer supervisors per worker, higher quality and productivity, and shorter delivery times than the traditional plant and also has $11 \%$ higher pay and lower turnover of the workforce. The lean plant has a more collaborative relation with Adidas staff and was more compliant with the firm's code of conduct.

Similar findings occur in a comparison of two Nike apparel subcontract plants in Mexico (Locke and Romis, 2007). The two plants were matched on product (T-shirts) and size with one having Mexican owners and the other Taiwanese ownership. The Mexican-owned plant has implemented some lean practices, including cellular production with job rotation and some responsibility for quality, maintenance, and improvement activities, while the Taiwanese plant follows traditional methods (i.e. specialized, repetitive jobs, close supervision, and inspection-based quality). The workers in the lean plant receive much more training to be able to handle job rotation, team work, equipment maintenance, and quality control than employees in the traditional plant. The result is higher productivity (150 T-shirts per day versus 80 per worker) and higher quality (40\% fewer sewing defects) in the lean plant. In addition workers in the lean plant participate more in decisions involving production planning and operations and reported higher job satisfaction. Overtime is voluntary in this plant while it is forced in the other plant (and at times over the 60 hour maximum in Nike's Code of Conduct). The workers in both plants have the same base 
pay, but in the lean plant they received an average weekly paycheck that was $21 \%$ higher due to productivity bonuses and incentives for attendance, punctuality and overtime. Nike staff also found it easier to work with the lean facility and provide more assistance to it in upgrading technology and operations. The authors conclude that "through the introduction of lean manufacturing techniques, Plant A [the lean plant] not only enhanced its competitiveness but also improved working conditions.” This example illustrates the importance of addressing the root causes of poor working conditions rather than focusing exclusively on enforcing corporate codes of conduct to improve conditions in overseas plants, which have often not achieved the desired results (Locke, et al, 2007).

In contrast a supplier that successfully implements a lean system will experience continually increasing quality and productivity over time making it more competitive. In fact productivity differences between lean and traditional plants can be eight to one or more largely offsetting the wage differentials with developing countries (Bernstein, 2001). In some cases this has even allowed manufacturing of lowtechnology products to remain in the industrialized countries (examples are New Balance shoes and American Apparel in the U.S. and Zara clothing in Spain). Even if the wage differential is not fully offset by higher productivity, the higher quality and the quicker response time can be major competitive advantages. Shorter lead times also mean lower inventories throughout the supply chain, lowering the substantial costs associated with them.

Production theory adds to these reasons for higher productivity the morale and skill effects of training workers and involving them in quality and process improvement activities. It would appear that the MNE's should be able to absorb the costs of training and higher wages and still be profitable given the small share labor costs are of the final product price. Moran (2002) cites some figures for the year 2000. In Nicaragua the labor cost (wages and benefits) per pair of jeans was $\$ 0.66$ while these jeans sold at retail for $\$ 21.99$. The wage and benefit cost for a women's coat manufactured in Hong Kong and selling in the U.S. for $\$ 99$ was $\$ 0.84$. A sport shoe produced in Indonesia that sold in the U.S. for $\$ 100$ incurred a wage cost of $\$ 0.40$. New Balance, in contrast, produces many of its shoes in the U.S. at a labor cost of $\$ 4$ per pair compared to $\$ 1.30$ per pair for shoes it sources in China even though wages and benefits are $\$ 14$ per hour in the U.S. and only $\$ 0.40$ per hour in China. Much higher labor productivity in the U.S. (24 minutes of labor to make a pair of shoes versus 3 hours in China) accounts for the smaller differential in labor costs per pair than wage rates per worker. U.S. workers get constant training, do a variety of tasks, and work in teams which along with greater automation account for the large productivity difference between China and the U.S. The remainder of the difference in labor costs New Balance figures is made up through a shorter, faster supply chain resulting in lower inventories and quicker response to demand changes. For these reasons the company is shifting more of its production back to the U.S. (Bernstein, 2001).

Another tenet of the lean philosophy is that if one partner in a supply chain prospers, the others also will benefit creating a virtuous cycle. This is perhaps most easily seen with a supplier who improves quality and productivity allowing its customers to offer higher quality products and lower their prices. The supplier benefits as the customer improves its competitiveness and increases its sales and then buys more from the supplier. A recent study in Spain confirms these results. Valenzuela and Villacorta (1999) examined supply chains in Spain and found that cooperation among supply chain partners improved the quality of products, reduced delivery time, and made the supply chain more agile. They found that for these results to be achieved firms must have an ethical quality to their dealings generating trust and improving communications.

A corollary of the lean production philosophy is that for a supply chain partner to continuously improve, they must earn sufficient profits to invest in upgrading their plants and equipment and training their workforce to be more productive. Therefore, in lean supply chains there is no desire to "squeeze" suppliers to extract lower prices if this leaves the suppliers with insufficient profits to invest in new technology and training. A "fair" profit for all supply chain partners is what is sought so that all will share in the growth of the supply chain. The implication for the global supply chain using subcontractors in developing countries is to assure that prices paid are sufficient to allow the suppliers to become capable suppliers in the lean sense.

The productivity and quality improvements resulting from lean production practices are largely driven by employee skill and morale effects. These will be explored in the next section. 
A key part of the lean production philosophy is that employees are assets rather than costs (Ohno, 1988). This, of course, is not the way in which many MNE's using foreign subcontractors think of the employees of those subcontractors, and most probably do not think of their own employees in that way either. The justification for the view of employees as assets revolves around the major role they play in creating high and continuously improving quality and productivity. In traditional firms managers and engineers develop methods of improving quality and productivity. In lean firms, the workers do it through kaizen and jidoka, with managers and engineers training and supporting them. In these lean firms most employees come up with multiple suggestions each year to do their jobs better, safer, faster, and more efficiently, often being rewarded with recognition and financial gains. Multiplied by hundreds or thousands of ideas generated in a typical manufacturing facility in a year, the improvements are incremental but are cumulative and can be substantial over time. This will not happen, however, unless the workforce is both trained and motivated to contribute. David Batstone points this out in his book Saving the Corporate Soul \& (Who Knows?) Maybe Your Own (2003) and cites examples of firms pursuing these practices.

In the typical sweatshop, workers receive minimal training and only in specific job skills. They are frequently paid on a piece-rate basis and quality is inspected into the product. They work long hours and often six or even seven days a week in uncomfortable and unsafe conditions. Their pay is subsistence, if that, and they have few benefits. If they can find a better job they leave. Employees working under these conditions have no incentive to offer ideas to improve operations, and even if they did, do not have the training in quality and productivity improvement methods necessary to do so. The result is an operation that only meets minimal quality and delivery standards and does not improve over time. Employers operating these sweatshops have little incentive to invest in training of the workforce as long as they can compete solely with low wage costs. The high turnover of the workforce discourages these firms from investing in training. However, eventually the work will move elsewhere as the country develops economically and wage rates inevitably rise, or the exchange rate moves against them, without productivity gains.

In a lean production system training is the key to developing a productive workforce as morale alone is not sufficient. Workers cannot practice jidoka or kaizen without training in the methods of quality and process improvement, no matter how motivated they are. Without the knowledge that comes from such training, they do not know how to improve the process in a systematic and scientific manner. Fortunately, the tools they need do not require extensive training; simple methods such as flowcharting, Pareto analysis, cause-and-effect analysis, and statistical control charts can be learned sufficiently well to be useful with a few weeks of training. It may take a little longer to develop multiple task skills so that workers can work in teams and cells to increase the flexibility of the plant. For a MNE willing to invest in these types of training, the resultant benefits can be substantial. Even if wages were doubled (in Indonesia this would be from $\$ 1.25$ to $\$ 2.50$ a day) the productivity and quality payoff would easily offset this. The workforce would also likely experience less absenteeism and turnover. But the benefits would not be immediate, except perhaps for lower absenteeism and turnover. It takes substantial time, often measured in years, to implement a lean production system so a firm would have to believe in the long-run benefits to incur the initial cost disadvantage of the investment in training and skill development.

An additional effect on employee morale of lean practices is the continuous process improvement that is emphasized in these systems. Often process improvements are targeted at improving ergonomics for the worker and eliminating dirty, dangerous and difficult tasks Since in a lean system employees at all levels are involved in process improvement activities they will often identify ways to improve safety and the quality of work life benefiting both themselves and the company through higher productivity and quality. Pride in the accomplishment can also be a motivator.

Costco has a policy of paying wages above the standard in retailing and provides more benefits, but Costco believes the lower turnover and higher productivity that result more than offset these higher payroll costs. There is evidence to support this belief. Its labor and overhead costs are $9.8 \%$ of sales compared to Wal-Mart's $17 \%$, and it generates $\$ 13,647$ in profits per employee versus $\$ 11,039$ at WalMart. Employee turnover is 6\% a year at Costco compared to 21\% at Wal-Mart. The CEO of Costco, James D. Sinegal, states that "Paying your employees well is not only the right thing to do but it makes for good business" (Holmes and Zellner, 2004).

The linkages between the production channel and shareholder value are presented in Figure 2. 
The firm with sustainable supply chain practices, as defined in this paper, is utilizing lean production and quality management practices. These programs are process-oriented and depend on the employees to be continually making efficiency and quality improvements. This necessitates investing in training the workforce to have the requisite skills and providing wages and working conditions that foster motivation. The result is improvements in processes that boost the firm's quality and productivity. Lower costs, in turn, lead to increased profits and ultimately contribute to higher share prices.

Figure 2

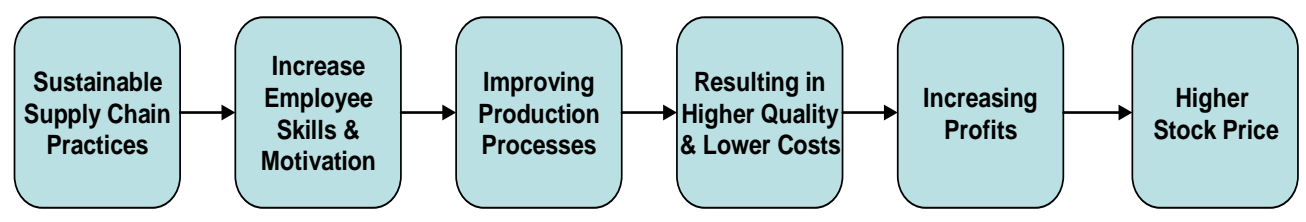

Sustainable Supply Chain Linkages: The Production Channel

\section{Reduction of financial risk with sustainable supply chain practices}

It is possible there may be benefits from reduction of financial costs and risk due to corporate social responsibility. There are several relationships between CSR and financial results by which this may occur. In this section these will be explored. They will usually be difficult to quantify, as are the revenue and cost benefits discussed above, but could be significant, especially in a long-run sense.

A business firm is exposed to many types of operational and financial risks. The manner in which it operates can heighten or lessen these risks. Consumers, employees, shareholders, suppliers, and governments are increasingly litigious, especially in the United States. U.S. firms may even be sued in U.S. courts for their corporate practices abroad under the Alien Tort Statute, and their have been recent instances of such suits (Schrage, 2003). Firms spend substantial amounts of money building risk management infrastructures and policies and insuring against these risks. Any strategic and operational policies and practices that lower these risks can be financially beneficial to the firm.

In the area of consumer risk, developing products and services that lessen the chance of injury is a 
sound practice to reduce product liability claims and settlements. Lean product design practices that use a concurrent engineering approach and involve consumers and suppliers on the design team are likely to result in better product designs (Sobek II, et al, 1998). However, the likelihood of lawsuits and claims may also be reduced by creating strong brand equity with consumers. I am not aware of any confirmatory research on this issue, but it seems plausible that customers are less likely to sue firms that they believe have good products and services and are ethical in their business practices.

The same argument could be made with employees. Firms that treat their employees as assets rather than costs are much less likely to have disgruntled employees venting their anger through discrimination, disability, sexual harassment, and unlawful dismissal lawsuits and claims. The increased motivation and loyalty that result could lessen the desire to file such grievances. Of course, socially responsible firms are probably more likely to have policies in place to assure that the conditions leading to lawsuits are not present. Again, I do not know of studies confirming this proposition, but it seems plausible.

Suppliers who believe that their customers deal with them in an ethical way are also less likely to sue these firms. The interaction and communication necessary to develop such trust also reduces the chances of disputes degenerating into legal action. This may be particularly important in global supply chains where legal remedies to business disputes are difficult and costly to attain. Ethical supply chain behavior targeted at developing an integrated, partnership relationship among all supply chain members should reduce the possibility of legal disputes.

For similar reasons other stakeholders that may file legal action against a corporation such as shareholders and governments may also be less likely to do so if the firm is seen as ethical and has a positive public image. Once a firm's reputation is damaged, it may be that it is more likely to become the target of lawsuits from all types of stakeholders. In addition, regulatory risk may be increased as governments respond to allegations of unethical behavior by creating new laws and restrictions on corporate activity. The reduced possibility of becoming embroiled in costly lawsuits from various aggrieved stakeholders could substantially lessen the associated risk management and insurance costs that firms must incur to protect themselves. Godfrey (2005) suggests that corporate philanthropy can create "moral capital" that provides "insurance-like protection" to the firm. Other areas of CSR could be hypothesized to provide similar moral capital.

A further possible mechanism of risk reduction resulting from socially responsible behavior in the production area is due to improvements in quality and the production process and improved safety in the workplace. The jidoka and kaizening activities inherent in lean supply chains make production processes more efficient, reliable, and safe while improving quality. The product liability claims resulting from defects could be reduced as quality improves. Additionally, firms following lean approaches are continually working to improve product design by linking with customers and suppliers. Potential product safety issues may be identified and resolved through product redesign before they become liability claims.

If in fact the firm has actually reduced the risk of legal claims and associated costs by acting in a socially responsible way, the uncertainty discount built into its stock price might also be reduced. Greater predictability of future cash flows, with less downside risk due to large claims settlements, reduces the expected volatility of those cash flows. The reduced risk premium from lower volatility incorporated into the rate to discount the cash flows increases the expected value of future cash flows. By portfolio theory the return to risk improvement should increase the share price of the ethical firm. Hart (2007) cites a recent study at the University of Michigan which found that firms rated highly on the ACSI customer satisfaction index indeed had less volatile cash flows and share prices.

If the brand equity effects discussed above are also present, the revenue cash flows may be less subject to recessionary downturns as the firm's products become less price-elastic. More stable and predictable revenues could also lower the volatility of the firm's cash flows and lead to a lower discount rate. Therefore, reductions in cash flow volatility may arise through the revenue channel as well increasing the valuation of the firm's shares. Roberts (1992) suggests that corporate disclosures of good sustainability practices may be interpreted by some investors as a sign of good management which also would make the firm's shares less risky.

The hypothesized cause and effect relationships between reduction of financial risk due to ethical supply chain behavior and share valuation is shown in Figure 3 below. Sustainable supply chain practices lead to reduced consumer lawsuits due to improved product design and greater brand equity. Employee lawsuits are also reduced by better treatment of employees and increased morale and commitment. The reduction in consumer and employee lawsuits reduces costs and creates more stable and predictable cash 
flows as does the reduced price-elasticity in the marketing channel. Less cash flow volatility should be rewarded by the financial markets with a lower cost of financing. This over time raises the firm's share price.

Figure 3

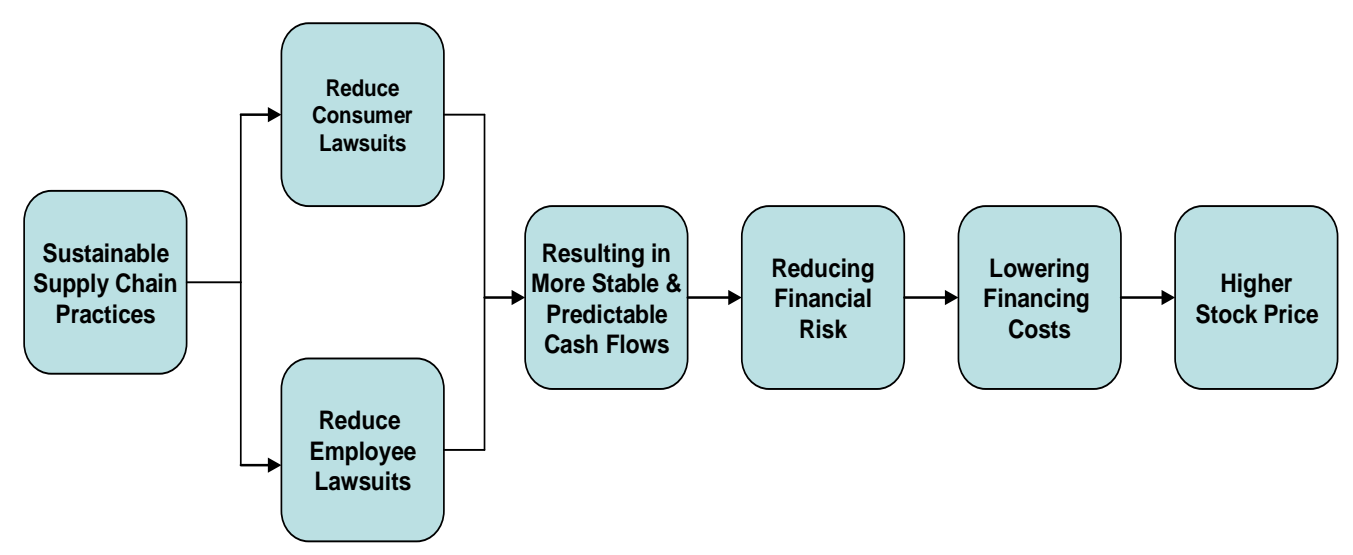

Sustainable Supply Chain Linkages: The Financial Channel

The issue of the effect of CSR on financial risk has not received much empirical attention but there are a few studies. Bassen, et al (2006) investigated 44 utility companies in the MSCI World Index. The utility companies are located in North America, Europe, Japan, Hong Kong, Australia, and Latin America and were ranked on CSR performance based on the quality of their CSR reporting. The authors found no clear relationship between financial performance and CSR but did find that financial risk was reduced. The authors conclude that for utility firms regulatory risk is the major source of risk reduction. A study by Lee and Faff (2006) found that there is a "corporate sustainability discount" in share prices. They compared global companies included in the Dow Jones Sustainability Index (DJSI) with a matched group of firms in the Dow Jones Global Index (DJGI). Firms in the DJSI are considered "leaders" in sustainability practices while those in the second group are considered "laggards". They found that the laggards outperformed the leaders in returns over the period 1998 to 2002. They attribute this to lower idiosyncratic risk of the leading sustainability firms reducing their required market return following portfolio theory. The lower idiosyncratic risk benefits the firm, especially larger firms, in terms of a lower cost of capital and required rate of return. This allows the firm to take on projects that would be rejected with a higher discount rate (cost of capital) and ultimately benefits shareholders. Interestingly, Lee and Faff do not find that firms rated high on Corporate Sustainability Practices (CSP) underperform the market as a whole, only the laggard group. Becchetti and Ciciretti (2006) also found that CSR leading firms have 
lower risk (measured as unconditional variance) than a matched sample over a fourteen year period. They found no significant difference in the risk-adjusted returns from the control group.

\section{$7 \quad$ Shareholder benefits of sustainable supply chain practices}

Conventional wisdom is that by finding the lowest cost supplier of a product, the firm's management is serving shareholder interests by maximizing corporate profits. The "market" is not believed to place value on corporate ethical behavior. However, some corporate managers do not accept this proposition instead believing that corporate social responsibility can actually create shareholder value. Dupont and Hewlett-Packard have adopted the CSR view in recent years developing new businesses to support this vision (Gunther, 2003). Dupont is pursuing products that use renewable resources like soy to promote sustainable growth and divested its oil refining subsidiary, Conoco, to provide financing for these new ventures. Hewlett-Packard is promoting the use of low-cost information technology to improve government services in India which the firm believes will lead to new business opportunities for H-P in the future (Dunn and Yamashita, 2003).

Recent research on equity market returns to CSR firms also casts doubt on the assumption that shareholders do not benefit from CSR activities. A sample of global firms ranked on social and environmental criteria from the Morgan Stanley Capital International World Index (MSCI) was compared for the period December 31, 1999 to October 27, 2003. The firms with the highest ranking outperformed those with the lowest by $23.4 \%$ over this period. Compared to the MSCI as a whole, the highest ranked companies outperformed by 3.8\% (Fittipaldi, 2004). The market appears to have rewarded their CSR efforts. This result conflicts with the Lee and Faff (2006) study cited above, illustrating the difficulty of separating the multitudinous nature of CSR practices on financial performance.

If in fact a firm realizes higher revenues, lowers costs, and reduced financial risk due to corporate social responsibility policies, then the market should reward the higher profits that are expected to result in the future. Since finance theory states that the valuation of a firm should be its discounted future cash flows, this valuation should be reflected in share prices. Managers of firms following traditional short-run cost minimization strategies would seem to believe that the market only rewards short-term performance. But the rationale developed in the preceding sections says future profitability should be higher with socially responsible supply chain behavior, even though short-term profitability may fall. In an equity market performing the way financial theory says it should, the long-run should prevail in valuation. The actual result hinges on to what extent the market buys the arguments for socially responsible behavior leading to higher long-run profitability. This is, of course, an empirical question ultimately and is at this point unresolved. Several studies (Waddock and Graves, 1997; Vershoor and Murphy, 2002) including the Fittipaldi one cited above, support the higher valuation view, but others have not (Wright and Ferris, 1997, Geczy and Stambaugh, 2003), and there are methodical issues in these types of studies that must be addressed (Margolis and Walsh, 2001). A comprehensive summary of 52 studies on this topic over the last 25 years found that 33 studies suggest a positive relationship between CSR and financial performance, 14 found no effect or inconclusive results, while 5 found a negative relationship (Roman, Hayibor and Agle, 1999). A meta-analysis of 52 separate studies was performed by Orlitzky, et al. (2003), including many of the same studies looked at by Roman, et al, and they found a positive correlation between CSR and financial performance (both measured in various ways). They point out that much of this research presents contradictory results, and there are statistical problems with many of the studies. A confounding factor is that managers may engage in "stakeholder neglect" where they place their interests above those of other stakeholders, including shareholders (Kolk and Pinske, 2006). Vogel (2005) reviews many of the studies on CSR and firm and mutual fund performance and "finds little support for the claim that more responsible firms are more profitable." He concludes that "CSR does make business sense for some firms in specific circumstances." Further research based on theoretical models of socially responsible behavior is needed to clarify the mechanisms and direction of the relationship between CSR and financial performance. In the next section such a model will be presented that identifies mechanisms through which sustainable supply chain practices can plausibly lead to improved financial performance and higher stock valuations. 
The discussion above identified several possible mechanisms of sustainable supply chain practices leading to higher profits and increased stock valuation. They are summarized in Figure 4. As can be seen on the diagram there are three main channels of effect and some cross-linkages among them.

Figure 4

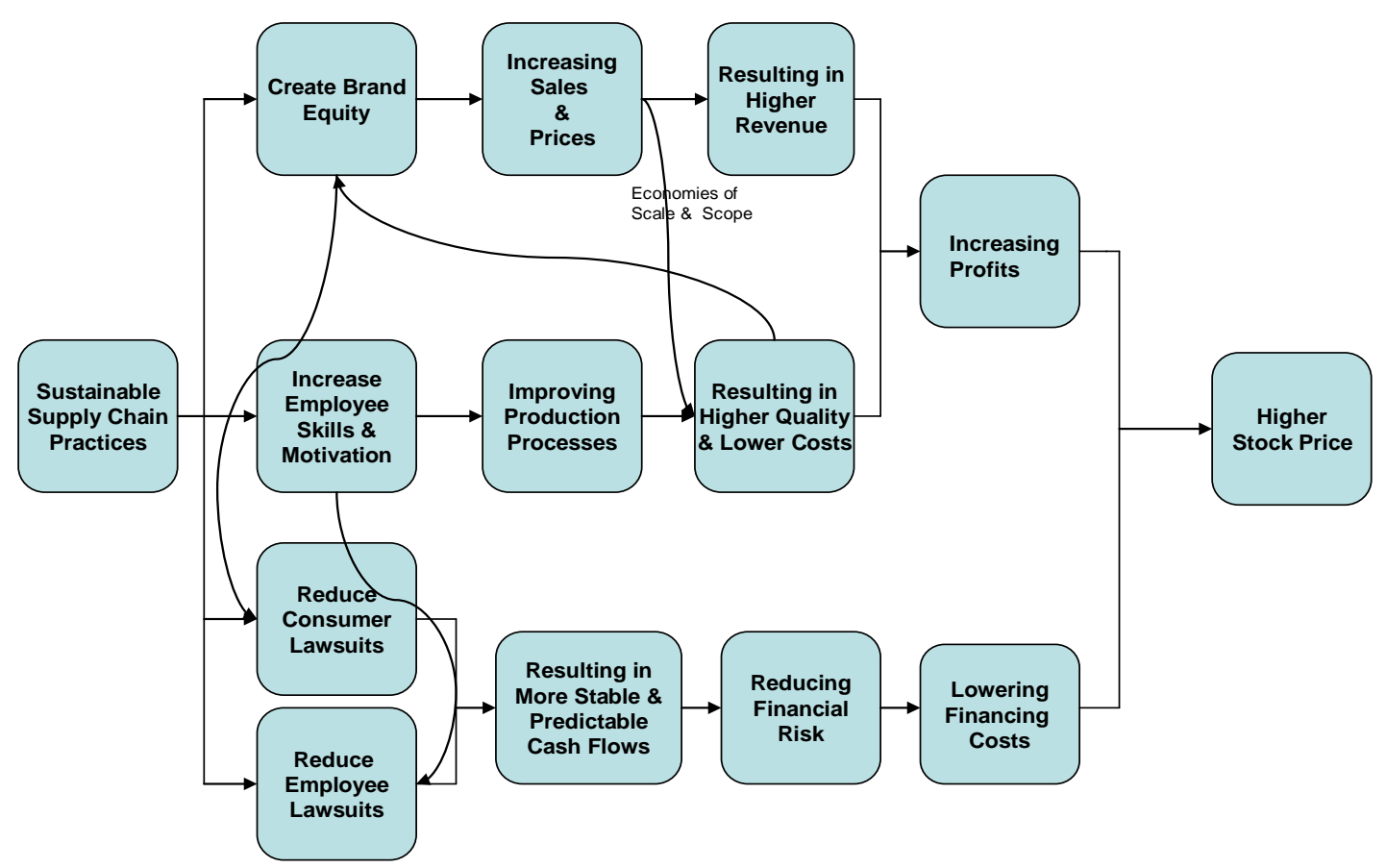

Sustainable Supply Chain Linkages

The first channel captures the effect of sustainable supply chain behavior on customers. Some consumers will prefer purchasing from firms that operate their supply chains in an ethical fashion which builds brand equity. This is turn leads to the ability of a firm to charge higher prices (either directly or through reduced need to discount their products) as well as increasing sales. Both effects lead to greater revenue for the ethical firm.

The second channel of influence of sustainable supply chain behavior is via the mode of production of the firm. A firm operating according to lean principles and practices may be able to attract better quality workers and likely will be more successful in retaining its best workers. This in turn justifies increased corporate expenditures on training both in specific job skills and process improvement and quality methods. These more capable workers are likely to be more motivated and committed to the firm. The more skilled and motivated employees not only do their jobs better (jidoka) but are willing and able to improve processes (kaizen) leading to higher quality and productivity. This leads to lower costs of production.

The third channel connecting ethical supply chain behavior with increased stock valuation is via reduced financial risk. The potentially decreased probability of claims and lawsuits from customers, employees, suppliers, and shareholders reduces the direct costs of insurance and settlements resulting from such claims, and may also reduce the risk premium incorporated into the discounting of future cash flows. Portfolio theory suggests that the return to risk ratio should improve, increasing share prices. 
There are two possible cross-linkages between the customer and employee channels. The first is improved production processes leading to higher quality and lower prices which increase brand equity as customers experience better performing and more reliable products, as well as higher perceived value. Some consumers may even believe that products from a company following sustainability practices will have better quality and reliability (McWilliams and Siegel, 2000). This in turn complements the sustainable firm's ability to charge higher prices and increase sales further enhancing its revenuegenerating ability.

A reverse cross-linkage is from the higher sales producing possible economies of scale and scope. These economies come from the more cost-effective volume of production as well as experience or learning curve effects as sales increase. This may decrease the cost of production. This will not only benefit that firm directly but also the entire supply chain as demand increases downstream. Not all firms experience substantial economies of scale, but for some it can be significant.

Cross-linkages also occur between the marketing and production channels and the financial risk channel. Higher brand equity may reduce the probability of customer lawsuits and improved production process and higher worker morale may decrease the risk of lawsuits from employees and customers. These are shown on the diagram as well.

The marketing, production, and financial effects, if realized, should improve the profitability of the firm. Greater revenues in the marketing chain of effect and lower costs in the production channel lead to higher net income and profits for the sustainable firm. The reduced financial risk provides an additional channel of influence on the firm's valuation possibly lowering the corporate cost of capital. The marketing and production channels increase profitability of the firm whereas the financial channel primarily reduces

risk. The result is an improved return-to-risk profile for the sustainable firm that is reflected in higher share prices and a greater market capitalization of the firm. This effect could be realized if the firm's shares are valued as finance theory says they should be; that is, as the present value of the future earnings stream. Since ethical corporate supply chain behavior mainly has long term economic effects, this would be reflected in the long term future earnings of the firm.

The linkages shown in Figure 4 are theoretical and by no means certain to occur in a sustainable supply chain. But based on production, marketing, and finance theory, one can make a case for these possible economic benefits of sustainable supply chain behavior. They will not appear quickly or easily given the difficulty of changing corporate cultures particularly in global supply chains where different cultural norms and business environments complicate the challenge (Mefford, 2006). The experience of firms transforming themselves to a lean production system is that it takes years to fully implement, and probably even longer in an international context. Patience and a long term perspective are necessary for corporate managers to make the types of changes that may not pay off for years in terms of higher profitability. But for those firms that persevere, the rewards are potentially great in terms of profitability and increased valuation of the firm, and the superior financial performance is likely to persist for years (Roberts and Dowling, 2002).

\section{$9 \quad$ Benefits to other stakeholders of a sustainable supply chain}

Shareholders are not the only beneficiaries of a sustainable supply chain. Other major stakeholders of the firm will also benefit from a sustainability approach to the supply chain. As the discussion above suggests consumers and employees receive some tangible and significant benefits as well. The environment and the communities in which firms operate will also be beneficiaries. Benefits to these stakeholder groups will be discussed in this section and the model developed above expanded to include them.

Customers are clear beneficiaries of the lean production methods suggested in the previous sections. A lean system results in higher quality products and services produced more efficiently. It responds more quickly to changes in consumer demand resulting in fewer out-of-stock conditions and faster delivery when the entire supply chain is integrated and is jointly pursuing a lean approach with short lead times and quick delivery (e.g. Zara and Dell). Design of new products is more integrated and faster fostering better response to new technology and changes in customer tastes. These attributes of lean systems all produce more value in the services and products for customers.

Employees benefit in several ways from the introduction of lean methods. They receive higher 
pay and benefits as firms realize the necessity of retaining and motivating their workers. They are given more training to provide them the skills necessary to do multiple tasks and work in teams. They also are trained to engage in problem-solving, quality control, and process improvement activities. Motivation may increase due to greater involvement and more interesting and varied tasks. This makes them more productive offsetting the higher wages and benefit costs. They also will have more job security in general in a lean firm because of its enhanced competitiveness.

Adoption of a lean production approach may also contribute to better environmental performance (King and Lennox, 2001, and Field, 2006). The emphasis in JIT on waste reduction of all types often leads to reductions in energy and material usage decreasing environmental pollution. Eliminating muda (waste in Japanese) is the major focus of lean systems. Energy usage is specifically identified as one of the seven major types of waste in production (Ohno, 1988). The practice of jidoka and kaizen, while improving production processes, contribute as well to reducing scrap and rework with concomitant reduction in material and energy usage. Handfield, et al (2005) argue for an "environmental supply chain strategy" that integrates environmental issues into the supply chain by stressing materials management practices that reduce cost through elimination of waste.

Another linkage between environmental and labor practices in firms is in the quality area. The methods used by firms to cut pollution and waste are often the same as are used in quality improvement efforts such as Total Quality Management (TQM) and Six Sigma (Gorman and Krehbiel, 1997; Hanna and Newman, 1995). These include cross-functional teams, root-cause analysis, extensive use of data collection and statistical methods, Pareto Analysis, and others. Firms may find that as they focus on improving their environmental performance they may also improve production processes resulting in increased efficiency and higher quality (Porter and van der Linde, 1995). A recent study lends empirical support to this hypothesis. Pil and Rothenberg (2003) examine global auto assembly plants and find that "superior environmental performance can be a significant driver of superior quality." Use of employee teams may be an effective way in which to link environmental and operational process improvements (Hanna, et al. 2000).

The community is another stakeholder group that will benefit from firms adopting lean systems. Higher productivity and quality leads to greater sales and profits. The enhanced competitiveness of the firm results in job security and job creation. Suppliers of goods and services to the firm that reside in the community also benefit through more business. In addition the higher wages paid in such firms give the employees greater spending power. The community thus is a major beneficiary of sustainable supply chain practices. Community can be interpreted to be more than a single city but rather a whole region or even a country.

Figure 5 expands the shareholder model illustrated in Figure 5 to encompass this broader group of stakeholders. The interior circle shows the lean production effects on employees and customers and shareholders as a virtuous cycle that is self-perpetuating, or sustainable in an economic sense. The benefits to the stakeholders are shown on the perimeter as consequences of this virtuous circle emanating from the

point in the cycle where they primarily occur. For example, lean production by focusing on reducing muda results in less waste and energy usage benefiting the environment. More training and higher pay benefit employees of the lean firm. Customers receive greater value because of the higher quality products and lower prices. Shareholders receive higher dividends and appreciating share prices from the greater profits of the lean firm. And the community receives job creation and job security from the enhanced competitiveness of the lean firm. 


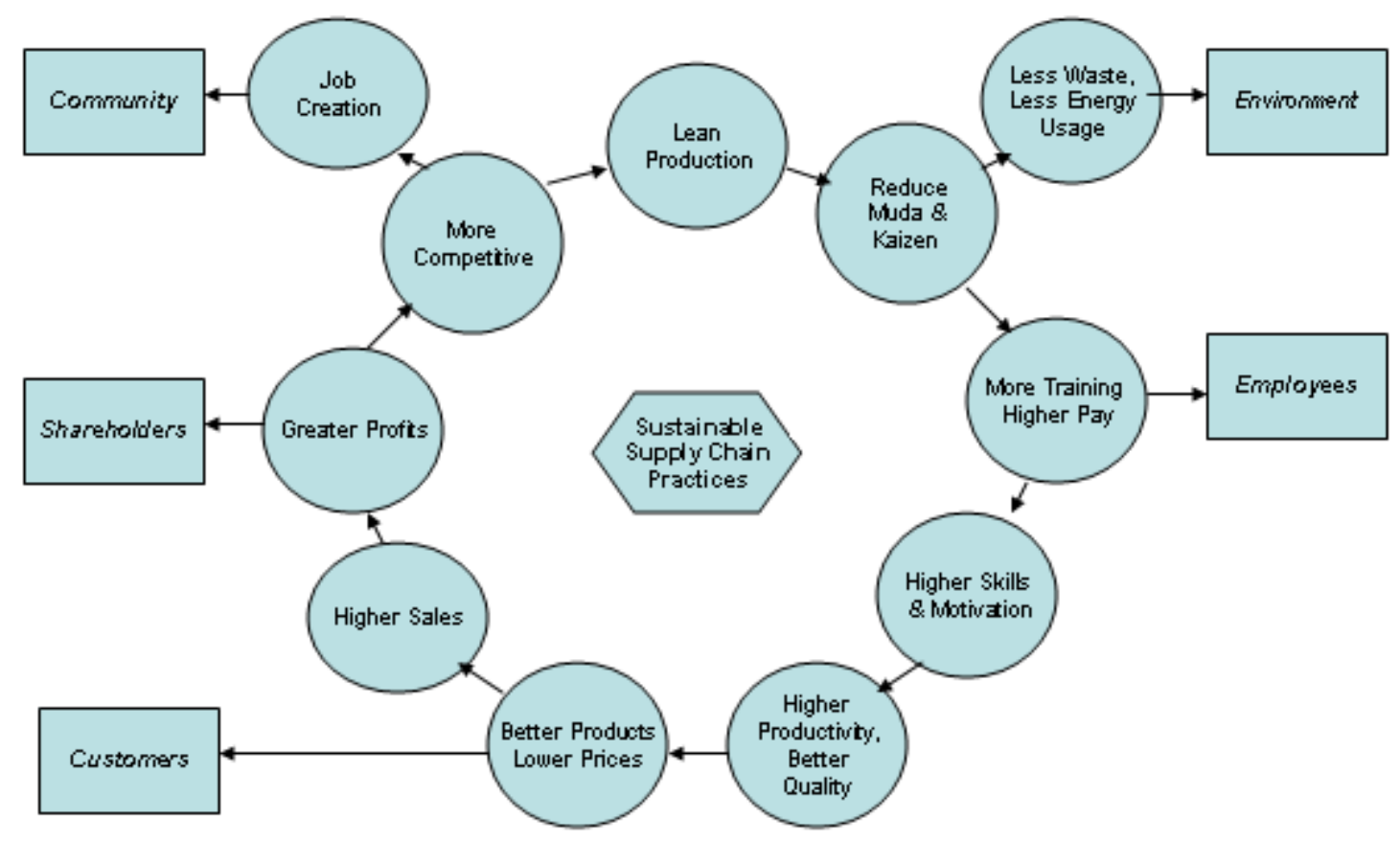

\section{Stakeholder Benefits from a Sustainable Supply Chain}

\section{Discussion and managerial implications}

There is some tentative evidence in support of this model in research of Berman, et al. (1999). They evaluated several dimensions of corporate social responsibility and their relationship to financial performance (measured as return on assets and equity) and found only CSR practices related to employees and customers directly affected financial results. Other components of CSR such as community involvement, diversity programs, and environmental practices did not correlate directly with financial performance. Of course it is possible that corporate activities in these other areas indirectly influence financial performance through their effect on the two key stakeholder groups of employees and customers. For example, involvement of the firm in community improvement activities may attract and retain better employees (Pereira, 2003). The Berman, et al. study does not evaluate the effect of CSR on stock valuation nor the impact on financial risk. Johnson (2003) proposes a continuum of firms from those engaging in illegal activities to those pursuing CSR for purely moral reasons. He suggests that those that engage in CSR for strategic reasons, rather than moral ones, will realize the greatest benefit in terms of financial returns on those efforts. He believes that the financial benefits will primarily accrue through the mediating effect on employees and customers.

Porter and Kramer (2006) argue that "Strategic CSR" is symbiotic with the firm and its stakeholders both benefiting from the firm's sustainability practices. Strategic CSR targets those social issues that are closely tied to the company's business providing greater leverage to both increase the firm's competitiveness and mobilize the firm's resources and capabilities to benefit stakeholders. Sustainable 
business practices for companies with global supply chains critical to their competitiveness would seem to meet this criterion. Others have argued that CSR must be strategic and selective to improve financial performance. Baumol (1991) emphasizes sustainability practices in the environmental and employee areas that raise productivity. Burke and Logsdon (1996) discuss the economic benefits of CSR activities that are central to the firm's mission and highly specific, proactive, visible, and voluntary.

Many social activists would claim that it is irrelevant whether CSR increases or decreases shareholder value since the firm has a moral obligation to benefit society (Clarkson, 1995; Donaldson and Preston, 1995; Scherer and Smid, 2000; Pierlott, 2004). They view the firm as having multiple stakeholders, and shareholders are not necessarily the most important of these. The firm, as a social institution, with its powerful influence on economic activities, has a moral responsibility to try to better society. To only engage in ethical corporate behavior because it is economically advantageous to do so is seen as disingenuous. This argument, although appealing to many philosophically, is unlikely to result in much movement toward greater corporate social responsibility in most capitalist countries. The Friedman view still dominates in most boardrooms and executive suites, and many firms are unlikely to change their practices unless they see an economic benefit to doing so, or are required by law to change (Husted and Salazar, 2006: Bradley, et al, 1999). It is often difficult to convince a CEO or a CFO on moral arguments alone (Lane and Sage, 2003). Therefore, theoretical and empirical evidence in support of ethical corporate behavior leading to greater shareholder value is useful if one believes firms should increase their CSR efforts. McWilliams and Siegel (2000) argue that "managers should treat decisions regarding CSR as they treat all investment decisions" in proposing a cost-benefit framework. There may also be increasing global pressure for convergence on standards in areas like the environment, corporate governance, and working conditions that also motivate increased attention to these issues (Davis, et al, 2006).

It does appear that an increasing number of firms are incorporating sustainability criteria into their strategies for managing their supply chains. A survey by A.T. Kearney, the consulting firm, in 2007 found that $36 \%$ of the firms surveyed have done so. Since typically at least $50 \%$ of a products value, and often as much as $80 \%$, is derived from suppliers, linking supply chain and sustainability strategies appear to be essential to remain competitive. An integrated strategy defines the firm's sustainability strategy and outlines how it will be implemented in its supply chain. This may involve codes of conduct and rewards and penalties for compliance, but as several studies above illustrated, a collaborative approach with the buyer working with suppliers is often more effective. One firm that has chosen this approach is HewlettPackard which shares its expectations and best practices with its suppliers (Snell, 2008). HP has found that for this process to work it has had to develop its procurement personnel to fill an expanded consultancy role.

One final consideration in implementing sustainability practices in a global supply chain is the difficulty of overcoming cultural, environmental, and communication differences. As one human resources manager in China commented in the Adidas article cited above (Frenkel and Scott, 2002), "We develop these labor practices because this is the adidas way. The workers get educated in what their rights are, which is a positive thing. On the other hand, it's Western companies determining what their rights are, which I don't feel is right - they are imposing certain standards in a different environment.” How does a firm overcome this type of resistance? One approach is a collaborative instead of a compliance approach (Frenkel and Scott, 2002; Locke and Romis, 2007). The collaborative approach involves the buyer working closely with the supplier to not only see that the code of conduct is followed but upgrading the production system to eliminate the "root cause" of the poor working conditions-low quality and productivity forcing the supplier to compete mainly on price. Lean production practices are fully supportive of the collaborative approach and result in a win-win-win situation for the buying firm, the supplying firm, and the workers at the supplier. The buyer receives lower cost and better quality products, the supplier increases its quality and lowers its cost through higher productivity, and the workers can share in the increased competitiveness of both firms. The footwear and apparel cases cited above illustrate these benefits.

\section{1}

\section{Conclusions}

The model proposed in this paper develops some mechanisms whereby corporate social responsibility practices could lead to increased competitiveness, profitability, and valuation of the firm. The marketing effects result from greater customer loyalty and brand equity which lead to higher revenue 
and profits. On the production side implementation of state-of-the-art practices such as lean manufacturing result in better working conditions, employee morale, skills and participation leading to better quality and higher productivity reducing costs. A financial effect occurs because of the greater predictability of cash flows and reduced risk resulting in a lower cost of capital. There are some feedback and interactive effects between these three channels that synergistically produce higher profits and increased shareholder returns.

This model has yet to be empirically tested in its entirety. There has been some relevant empirical work that supports pieces of the overall model (see previous citations). As mentioned above, there have been a substantial number of studies attempting to assess the effect of Corporate Social Responsibility on financial performance (FP). However, these studies often have used a survey approach to define CSR (such as Fortune magazine's annual ranking of most admired companies), a multitude of variables for sustainable practices (often aggregating these together as a composite index), and many different measures of financial performance. Some of this research suffers from statistical sampling and measurement problems. The many different components of CSR which are included in these studies, while they may well be worthwhile on a moral basis, may not contribute to improved financial performance. Rowley and Berman (2000) propose that a theory-based approach be used for future research on the CSR-FP link. The model presented in this paper is an attempt to do this. To empirically test it, samples of firms with sustainable supply chain practices would be selected based on the criteria incorporated in the model and compared to a matched sample of firms not employing the practices. Financial performance would be measured as returns to shareholders over a sufficiently long period to capture the effects.

\section{REFERENCES}

Anderson, E.W., C. Fornell, and R.T. Rust (1994) "Customer Satisfaction, Productivity and Profitability: Differences between Goods and Services,” Marketing Science, 16(2), pp.129-145.

Auger, P., P. Burke, T.M. Devinney and J.J. Louviere (2003), "What Will Consumers Pay for Social Product Features?” Journal of Business Ethics, 42, pp.281-304.

Bassen, Alexander, Meyer, Katrin, and Joachim Schlange, 2006, "The Influence of Corporate Responsibility on the Cost of Capital," University of Hamburg Working Paper (available on SSRN:www.ssrn.com/abstract=984406).

Batstone, David (2003), Saving the Corporate Soul \& (Who Knows?) Maybe Your Own, Jossey-Bass: San Francisco, CA.

Baumol, W.J. (1991), “(Almost) perfect competition (contestability) and business ethics,” In Baumon, W.J. with Blackman, S.A.B. (Eds), Perfect Markets and Easy Virtue: Business Ethics and the Invisible Hand, Cambridge, MA: Blackwell Publishers, pp.1-23.

Becchetti, Leonardo and Rocco Ciciretti (2006), "Corporate Social Responsibility and Stock Market Performance,” Working Paper, University of Rome, Department of Economics, March.

Berman, Shawn, Andrew Wicks, Suresh Katha, and Thomas Jones (1999), "Does Stakeholder Orientation Matter? The Relationship Between Stakeholder Management Models and Firm Performance," Academy of Management Journal, 42(5), pp. 88-506.

Bernstein, Aaron (2001), “Low-Skilled Jobs: Do They Have to Leave?” Business Week, February 24, pp. 94-95.

Bernstein, Aaron (2003), “Sweatshops: Finally Airing the Dirty Linen,” Business Week, June 23, pp.100102.

Bradley, M. Schipani, CA, Sundaram, AK, and JP Walsh (1999), “The purpose and Accountability of the corporation in contemporary society: Corporate governance at a crossroads," Law and Contemporary Problems, 62(3), pp.9-86.

Burke, L. and J.M. Logsdon (1996), "How corporate social responsibility pays off," Long Range Planning, 29, pp.495-502.

Clarkson, Max. B.E. (1995), “A Stakeholder Framework for Analyzing and Evaluating Corporate Social Performance,” Academy of Management Review, 20(1), pp. 92-117.

Davis, G.F, Whitman, M.v.N, and M.N. Zald (2006), “The Responsibility Paradox: 
Multinational Firms and Global Corporate Social Responsibility,” Working Paper,

Ross School of Business, University of Michigan, April.

Donaldson, Thomas and Lee E. Preston (1995), "The Stakeholder Theory of the

Corporation: Concepts, Evidence, and Implications,” The Academy of

Management Review, 20(1), pp.65-91.

Dunn, Debra and Keith Yamashita (2003), "Microcapitalism and the Megacorporation," Harvard Business Review, 81(8), pp.46-54.

Ferdows, Kasra, Michael A. Lewis, and Jose A.D. Machuca (2004), "Rapid-Fire

Fulfillment," Harvard Business Review, November, pp.104-110.

Field, Alan M., 2006, “Doing well by doing good,” Journal of Commerce, August 7, p.1.

Fittipaldi, Santiago (2004), "When Doing the Right Thing Provides a Pay-Off”, Global Finance, January, pp.18-22.

Friedman, Milton (1970), "The Social Responsibility of Business is to Increase Its Profits,” New York Times Magazine, 13 September, p.32.

Frenkel, Stephen J. and Duncan Scott, 2002, “Compliance, Collaboration, and Codes of Labor Practice: The Adidas Connection,” California Management Review, 45(1), pp.29-49.

Geczy, Christopher and Robert Stambaugh (2003), "Investing in Socially Responsible Mutual Funds”, Wharton School Finance Paper

Gorman, R.F. and T.C. Krehbiel (1997), “Quality Management and Sustainability,” Quality Management Journal, 4(4), pp. 8-15.

Gunther, Marc (2003), “Tree huggers, soy lovers, and profits,” Fortune, June 23, pp.98-104.

Handfield, Robert, Sroufe, Robert, and Steven Walton, 2005, “Integrating Environmental Management and Supply Chain Strategies," Business Strategy and the Environment, 14(1), pp.1-19.

Hanna, M.D. and W. R. Newman (1995), "Operations and the Environment: An Expanded Focus for TQM”, International Journal of Quality \& Reliability Management, 12(6), pp.38-53.

Hanna, M.D., W.R. Newman, and P. Johnson (2000), "Linking Operational and Environmental Improvement Through Employee Involvement," International Journal of Operations and Production Management, 20(2), pp.148-165.

Hart, Christopher W. (2007), "Beating the Market with Customer Satisfaction,” Harvard Business Review, March, pp.30-31.

Heskett, J.L., T.O. Jones, G.W. Loveman, W.E. Sasser Jr., and L.A. Schlesinger (1994), "Putting the Service-Profit Chain to Work," Harvard Business Review, 72(2), pp.164-175.

Holmes, Stanley and Wendy Zellner (2004), “The Costco Way”, Business Week, April 12, 2004, pp.76-77.

Husted, Bryan W. and Jose de Jesus Salazar (2006), "Taking Friedman Seriously: Maximizing Profits and Social Performance,” Journal of Management Studies, 43(1), pp.75-91.

Johnson, Homer H. (2003), "Does it pay to be good? Social responsibility and financial performance," Business Horizons, November/December, pp.34-40.

Keeler, Dan (2003), “Shaping Up,” Global Finance, July/August, pp.18-22.

King, A.A. and M.J. Lenox (2001), "Does It Really Pay to be Green? An Empirical Study of Firm Environmental and Financial Performance,” Journal of Industrial Ecology, 5(1), pp.105-116.

Klassen, R.D. and C.P. McLaughlin (1996), "The Impact of Environmental Management on Firm Performance,” Management Science, 42(8), pp.1199-1214.

Kolk, Ans and Jonatan Pinske (2006), "Stakeholder Mismanagement and Corporate Social Responsibility Crises,” European Management Journal, 24(1), pp.59-72.

Lane, Geoff and Cathy Sage (2003), "Corporate Social Responsibility: Trickier Than It Looks", European Business Forum, March.

Lee, Darren D. and Robert W. Faff (2006), “The Corporate Sustainability Discount Puzzle,” Working Paper, University of Queensland, Brisbane.

Liker, J.K. and T.Y. Choi (2004), "Building Deep Supplier Relationships,” Harvard Business Review, December, pp.104-113.

Locke, Richard, Kochan, Thomas, Romis, Monica, and Fei Qin, 2007, “Beyond 
corporate codes of conduct: Work organization and labor standards at Nike suppliers,” International Labour Review, 146(1/2), pp.21-40.

Locke, Richard and Monica Romis, 2007, "Improving Work Conditions in a Global Supply Chain, MIT Sloan Management Review, 48(2), pp.54-62.

Mahler, Daniel, 2007, “The Sustainable Supply Chain,” Supply Chain Management Review, 11(8), p.1.

Margolis, J.D. and J.P. Walsh (2001), People and Profits? The Search for a Link Between a Company's Social and Financial Performance, Lawrence Erlbaum: Mahwah, N.J.

McWilliams, Abigail and Donald Siegel (2000), "Corporate social responsibility and financial performance: correlation or misspecification," Strategic Management Journal, 21(5), pp.603-609.

Mefford, R.N. (2006), “Applying Information Technology in Global Supply Chains: Cultural and Ethical Challenges,” International Journal of Integrated Supply Management, 2(3), pp.170-188.

Moran, T.H. (2002), Beyond Sweatshops: Foreign Direct Investment and Globalization in Developing Countries, Brookings Institute: Washington, D.C.

Ohno, Taaichi (1988), Toyota Production System: Beyond Large-Scale Production, Productivity Press: Cambridge, MA.

Orlitzky, Marc, Frank L. Schmidt, and Sara L. Rynes (2003), "Corporate Social and Financial Performance: A Meta-analysis,” Organization Studies, 24(3), pp.403-441.

Pereira, J. (2003), “Doing Good and Doing Well at Timberland,” The Wall Street Journal, September 9, p.B1.

Pierlott, M.F. (2004), "Moral Considerations in Outsourcing to Foreign Labor," International Journal of Social Economics, 31(5/6), pp.582-592.

Pil, Frits K. and Sandra Rothenberg (1993), "Environmental Performance as a Driver of Superior Service Quality,” Production and Operations Management, 12(3), pp. 404-415.

Porter, M.E. and M.R. Kramer (2006), "Strategy \& Society,” Harvard Business Review, December, pp.7892.

Porter, M.E. and C. van der Linde (1995), “Green and Competitive: Ending the Stalemate," Harvard Business Review, 58(6), pp.120-134.

PWC (1999), “Corporate Social Responsibility Affects Reputation”, PricewaterhouseCooper, Press Release, September 30.

Reichheld, Frederick F. W. Earl Sasser, Jr. (1990), “Zero Defections: Quality Comes to Services,” Harvard Business Review, 68(5), pp.105-111.

Reinhardt, F. (1999), "Market failure and the environmental policies of firms: economic rationales for "beyond compliance” behavior," Journal of Industrial Ecology, 3(1), pp. 9-21.

Roberts, Dexter and Pete Engardio (2006), "Secrets, Lies, and Sweatshops," Business Week, November 27, pp.50-58.

Roberts, Peter W. and Grahame R. Dowling (2002), "Corporate Reputation and Sustained Financial Performance,” Strategic Management Journal, 23(12), pp.1077-1093.

Roberts, R. (1992), "Determinants of Corporate Social Responsibility Disclosure: An Application of Stakeholder Theory," Accounting, Organizations and Society, 17(6), pp.595-612.

Roman, Ronald M., Sefa Hayibor, and Bradley R. Agle (1999), "The Relationship Between Social and Financial Performance”, Business and Society, 38(1), pp. 109-126.

Rowley, Tim and Shawn Berman (2000), "A Brand New Brand of Corporate Social Performance,” Business and Society, 39(4), pp.397-418.

Russo, M.V. and P.A. Fouts (1997), "A resource-based perspective on corporate environmental performance and profitability,” Academy of Management Journal, 40(3), pp.534-559.

Rust, R.T., A.J. Zahorik, and T.L. Keiningham (1995), "Return on Quality (ROQ): Making Service Quality Financially Accountable”, Journal of Marketing, 59(2), pp. 58-70.

Scherer, A.G. and M. Smid (2000), "The Downward Spiral and the US Model Business Principles: Why MNE’s Should Take Responsibility for the Improvement of World-Wide Social and 
Environmental Conditions,” Management International Review, 40, pp.351-371.

Schrage, E. (2003), “Emerging Threat: Human Rights Claims,” Harvard Business Review, August, pp. 16-18.

Shah, Rachna (2006), “An Interview with James P. Womack: Future of Process Management and Implications for Management Students,” POMS Chronicle,13(1), pp.5-9.

Shingo, Shigeo (1988), Non-Stock Production: The Shingo System for Continuous Improvement, Productivity Press: Cambridge, MA.

Snell, Paul, 2008, “HP shares best practice for suppliers,” Supply Management, 13(3), p.10.

Sobek II, D.K., J.K. Liker, and A.C. Ward (1998), “Another Look at How Toyota Integrates Product Development,” Harvard Business Review, July/August, pp. 36-49.

Spear, Steven and H. Kent Bowen (1999), "Decoding the DNA of the Toyota Production System,” Harvard Business Review, September/October, pp. 97-106.

Ullmann, A. (1985), "Data in Search of a Theory: A Critical Examination of the Relationship Among Social Performance, Social Disclosure and Economic Performance of U.S. Firms," Academy of Management Review, 10(3), pp.540-557.

Valenzuela, Jose Luis Duran and Fernando Sanchez Villacorta (1999), “The relationships between The companies and their suppliers”, Journal of Business Ethics, 22(3), pp. 273-280.

Van Tulder, Rob and Ans Kolk (2001), "Multinationality and Corporate Ethics: Codes of Conduct in the Sporting Goods Industry,” Journal of International Business Studies, 32(2), pp.267-283.

Verschoor, Curtis C. and Elizabeth A. Murphy (2002), "The Financial Performance of Large U.S. Firms and Those with Global Prominence: How Do the Best Corporate Citizens Rate?” Business and Society Review, 107(3), pp.371-380.

Vogel, David J. (2005), "Is There a Market for Virtue? The Business Case for Corporate Social Responsibility,” California Management Review, 47(4), pp.19-45.

Waddock, Sandra A. and Samuel B. Graves (1997), "The corporate social performance -financial performance link,” Strategic Management Journal, 18(4), pp. 303-319.

Womack, James P. and Daniel T. Jones (1996a), "Beyond Toyota: How to Root Out Waste and Pursue Perfection,” Harvard Business Review, September/October, pp. 140-158.

Womack, James P. and Daniel T. Jones (1996b), Lean Thinking, Simon and Schuster: New York, NY.

Wright, P. and S. Ferris (1997), “Agency conflict and corporate strategy: The effect of divestment on corporate value,” Strategic Management Journal, 18(1), pp.77-83. 